\title{
From Chernozem to Luvisol or from Luvisol to Chernozem? A discussion about the relationships and limits of the two types of soils. A case study of the soil catena of Hrušov, Czechia
}

\author{
BARBORA STROUHALOVÁ ${ }^{1}$, ANNE GEBHARDT ${ }^{2,3}$, DAMIEN ERTLEN ${ }^{2}$, LUDĚK ŠEFRNA ${ }^{4}$, \\ KRISTÝNA FLAŠAROVÁ ${ }^{4}$, PETR KOLAŘÍK ${ }^{4}$, DOMINIQUE SCHWARTZ ${ }^{2}$
}

1 Institute of Archaeology of the Czech Academy of Sciences, Prague, v. v. i., Prague, Czechia; e-mail: strouhalova@arup.cas.cz

2 University of Strasbourg, Faculté de Géographie et d'Aménagement, Laboratoire Image, Strasbourg, France; e-mail: anne.gebhardt-even@inrap.fr, damien.ertlen@live-cnrs.unistra. fr, dominique.schwartz@live-cnrs.unistra.fr

3 Institut National de Recherches Archéologiques Préventives Grand Est Nord, Ludres, France

${ }^{4}$ Charles University in Prague, Faculty of Science, Department of Physical Geography and Geoecology, Prague, Czechia; e-mail: ludek.sefrna@natur.cuni.cz, kristyna.flasarova@natur. cuni.cz, petr.kolarik@natur.cuni.cz

ABSTRACT The patchy character of the distribution of Chernozems and Luvisols formed on loess is often observable on the pedological maps, on a large scale, in Czechia. The focus of the paper is to examine the features of the soil catena of Hrušov (Czechia), which is characterized by the simultaneous presence of Chernozem, Luvisol and Luvic Chernozem - without obvious environmental reasons. A catena of only 330 meters is considered a system of transformation between these soils. Along with field work and the pedological analysis, we used the soil micromorphology method to understand the processes of pedogenesis. We concluded that the presence of considerably different soil types on a small scale is due to intensive agriculture. We found that the present Chernozem is formed on the Luvisol by retrograde soil evolution, which included a shift in the vegetation, erosion, and recarbonation. The evolution of Luvisol in the lower part of the catena has been considerably modified.

KEY WORDS soil catena - chernozem - luvisol - soil micromorphology - Czechia

STROUHALOVÁ, B., GEBHARDT, A., ERTLEN, D., ŠEFRNA, L., FLAŠAROVÁ, K., KOLAŘÍK, P., SCHWARTZ, D. (2020): From Chernozem to Luvisol or from Luvisol to Chernozem? A discussion about the relationships and limits of the two types of soils. A case study of the soil catena of Hrušov, Czechia. Geografie, 125, 4, 473-500.

https://doi.org/10.37040/geografie2020125040473

Received February 2020, accepted July 2020.

CC Česká geografická společnost, z. s., 2020 


\section{Introduction}

Loess is a widespread type of sediment, which covers about one-fifth of the surface of Europe (Haase et al. 2007). It is the parent material of several types of soils. Chernozems and Luvisols are especially widely represented in Europe (Figure 1). In this paper, we review the existing concepts about the relationship between these soils which is described in the literature as (i) spatial or (ii) temporal. We continue by presenting new data on a Luvisol-Chernozem catena in Hrušov (Czechia) where the Chernozem and Luvisol coexist in very tight contact despite identical environmental conditions. We hypothesise that the site is a zone of transformation where one type transforms to another and discuss the processes participating on the soil's evolution. The study is based on the field descriptions, soil micromorphological observations and the bulk soil analysis.

\subsection{Spatial distribution of Luvisols and Chernozems}

Chernozems - with their thick black organo-mineral horizon - are considered as zonal soils that are typical for a dry continental climate (Dokuchaev 1883, FAO 2015). On the contrary, the formation of Luvisols is conditioned by a temperate oceanic climate and forest vegetation (Duchaufour 1998, Němeček et al. 2001, FAO, ISRIC, ISSS 2006; Baize, Girard 2008). These environmental conditions make the illuviation of clays and the textural differentiation between the eluviation $\mathrm{E}$ horizon and illuviation Bt horizon possible. On the continental scale of Europe, the distribution of the two soils seems to follow the climatic variations between the oceanic conditions in the West and the continental conditions in the East (Fig. 1).

When we focus on Czechia in Central Europe, we see that both types of loess soils are present. The environmental conditions of their distribution overlap (Table 1), the geographical distribution of Luvisols and Chernozems differ in the regional climatic conditions. Two factors are omitted for Chernozems in the defined conditions: the topography and past vegetation (Němeček et al. 2011). According to Hauptmann et al. (2009), both types of soils are mostly formed in plain areas, but they can be also formed in hilly areas and on plateaus. However, there are not currently existing Chernozems above $300 \mathrm{~m}$ a.s.l. of altitude in Czechia. The climax vegetation of the regions with the presence of both types of soils is land predominated by oaks (Quercetea) or oak-hornbeams (Carpinus - Quercetea; Chytrý, Kučera, Kočí 2001; Neuhäuselová 1998). On large-scale soil maps, a mosaic of Chernozems and Luvisols can often be observed. On the local scale and in the field, the origin of the spatial distribution of Chernozems and Luvisols is difficult to explain, because the climatic, topographical and geological conditions seem to be identical (Bailly 1972; Ložek, Smolíková 1978; Vysloužilová et al. 2014). These 
Tab. 1 - The environmental characteristics of the Chernozems and Luvisols in Czechia (Němeček et al. 2011)

\begin{tabular}{|c|c|c|}
\hline $\begin{array}{l}\text { Environmental } \\
\text { characteristic }\end{array}$ & Chernozem & Luvisol \\
\hline Climate & $\begin{array}{l}\text { Climate region B 1-3 } \\
\text { Mean annual precipitation (7) } 8-9^{\circ} \mathrm{C} \\
\text { Max. } 650(700) \mathrm{mm}\end{array}$ & $\begin{array}{l}\text { Climate region B 3-5 }(6) \\
\text { Mean annual precipitation } \\
7-9^{\circ} \mathrm{C} \\
450-900 \mathrm{~mm}\end{array}$ \\
\hline $\begin{array}{l}\text { Vegetation altitude } \\
\text { zonation }\end{array}$ & $\begin{array}{l}\text { 1-2 } \\
\text { Oak zone (Quercus spp. mainly Quercus } \\
\text { petraea agg.) and - Beech-Oak zone } \\
\text { (Fagus sylvatica-Quercus petraea agg.) }\end{array}$ & $\begin{array}{l}1-2(3) \\
\text { Oak zone (Quercus spp. mainly Quercus } \\
\text { petraea agg.), Beech-Oak zone (Fagus } \\
\text { sylvatica-Quercus petraea agg.) and } \\
\text { Oak-Beech zone (Quercus petraea agg. - } \\
\text { Fagus sylvatica) }\end{array}$ \\
\hline Soil moisture regime & Ustic & Limit between ustic and udic \\
\hline Parent material & Loess, sandy loess, marls & Loess, polygenic silts \\
\hline Topography & Not defined & Flat, gently undulating terrain \\
\hline Native vegetation & Not defined & Oak, oak-hornbeam forest \\
\hline
\end{tabular}

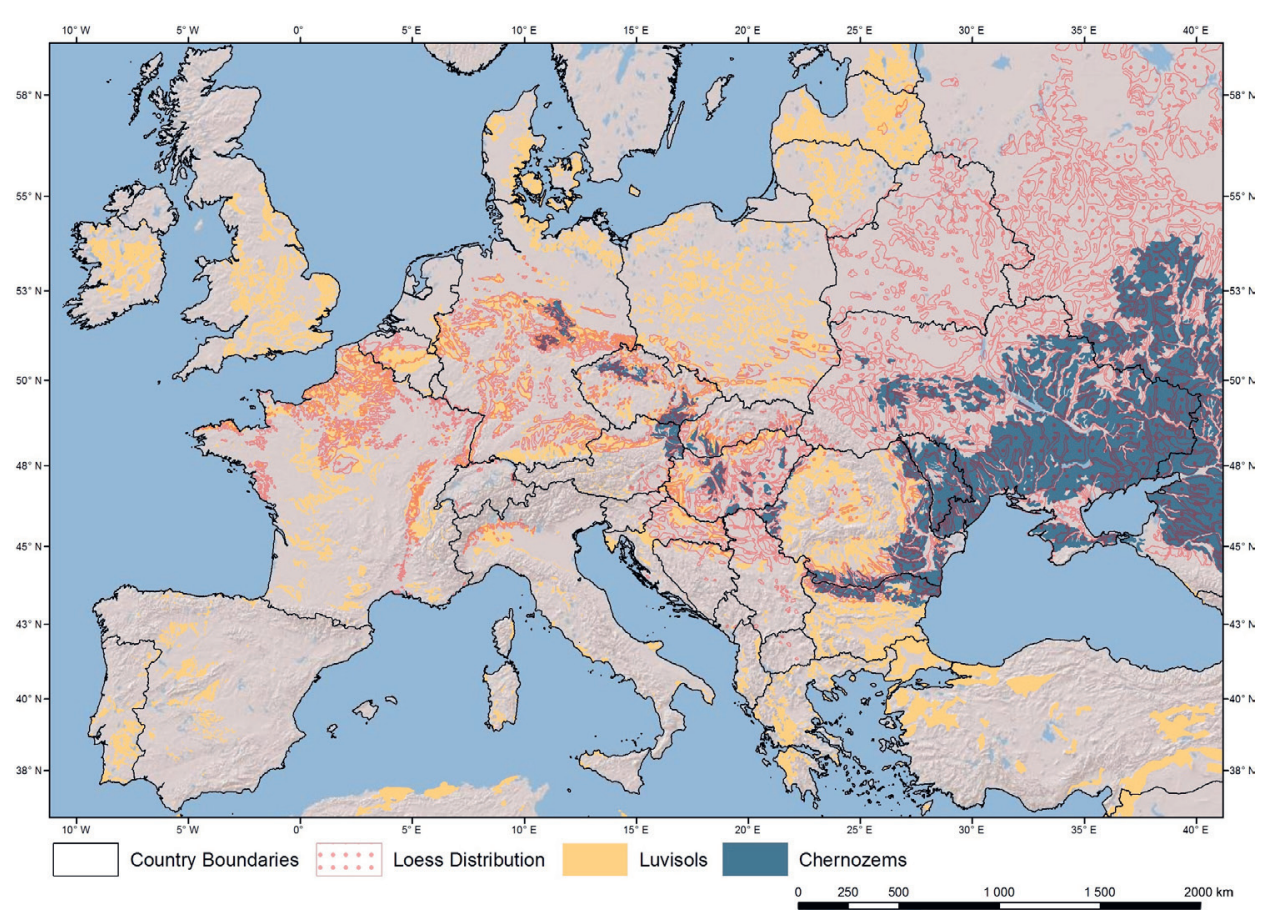

Fig. 1 - The spatial relationship of Chernozems and Luvisols. The distribution of loess (in red), Chernozems and Luvisols in Europe (Haase et al. 2007, ESDC 2013). 
observations show that there is a need for more in-depth studies to understand the role of environmental factors, in particular vegetation and paleo-environmental conditions, on the formation of these types of soils (Eckmeier et al. 2007).

\subsection{Temporal relationship of Chernozems and Luvisols in the Holocene}

Next to the spatial relationship of the two soils, there is a temporal relationship. Both soils are placed in the same series of development (Leser, Maqsud 1975). The Holocene evolution model from the initial loess to a Luvisol takes place under natural vegetation (Fig. 2, according to Lorz, Saile 2011). According to these authors, after the sedimentation of the upper Weichselian (Würm) loess, the initial calcareous soil develops under the steppe vegetation. The warmer and wetter climate in the Early Holocene (Preboreal and Boreal) allows the formation of a Calcic Regosol. The humic horizon thickens and at the end of the Boreal and the Chernozem was formed (Leser, Maqsud 1975; Lorz, Saile 2011; Scheffer, Meyer 1963). Forest conditions induced decarbonation and leaching of clays. The clay illuviation downwards the soil profile caused the lowering of the decalcification limit. This resulted first in the formation of a cambic horizon, then argillic horizon while preserving the superficial A horizon. Finally, Chernozem takes its Luvisol morphology with developed E and Bt horizons (Lorz, Saile 2011; Němeček, Smolíková, Kutílek 1990).

The transformation of a Chernozem into a Luvisol has been well studied in the North Caucasus: the successive constructions of tumuli has made it possible to preserve the stages of the genesis of a Luvisol following the replacement of a steppe by a forest (Alexandrovskiy 2000). The transformation of a Chernozem to a Luvisol has also been hypothesised upon by Hejcman et al. (2013) who discovered a buried A horizon of a Chernozem under a bell-beaker barrow (2500-2200 BC) in Central Moravia, even if the Luvisols are dominant in the region nowadays. In their view, the increasing annual precipitation and decreasing temperatures induced the degradation of Chernozems to Luvisols. The same evolution induced by the climate was described recently by Kabata et al. (2019) in southwestern Poland.

Scheffer and Meyer (1963) describe the development of an initial soil loess towards a Chernozem and a Phaeozem in southern Lower Saxony, Germany. The rate of development of this series and its control mechanism are carbonate dynamics and the lowering of the decarbonation limit (Scheffer, Meyer 1963; Rohdenburg, Meyer 1968). Decarbonation was controlled by climate change in the Holocene. It was minimal at the beginning of the Holocene, it strengthened at the beginning of the Atlantic with an increase in the pluviometry and the development of the forests. However, conversely, the decarbonation mechanism linked to climate change can be slowed down by various factors such as a high carbonate content of the 


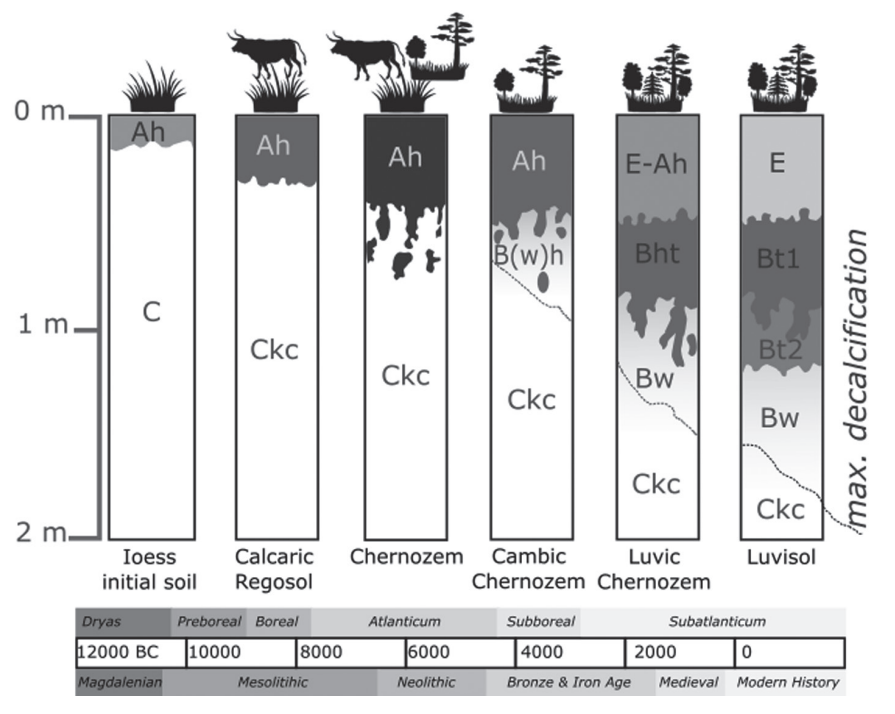

Fig. 2 - The temporal relationship of the Chernozems and Luvisols in the Holocene. Source: after Lorz, Saile 2011.

parent rock or the storage of calcareous groundwater from the Atlantic period. In this case, Gleyic and pseudogleyic Chernozems are formed (Scheffer, Meyer 1963; Fischer-Zujkov, Schmidt, Brande 1999). Carbonate dynamics are also considered as a crucial factor in persistence of Chernozems by von Suchodoletz et al. (2019).

The tight contact between the Chernozems and Luvisols (distinct Chernozem patches in the Luvisol area) is not explained by this evolutionary approach. According to the evolutionary model, the Chernozem is prevented from degradation by deforestation or by a climate change. Distinct patches of Chernozems in the Luvisol areas have been described as zones of ancient settlements and intensive agriculture (Ložek 1973, Kaba囚a et al. 2019), the heterogeneity of the parent material in higher carbonate contents (Altermann et al. 2005, von Suchodoletz et al. 2019) or as the consequence of prehistoric burning practices (Eckmeier et al. 2007, Kasielke, Poch, Wiedner 2019).

\subsection{Spatiotemporal relationship of Chernozems and Luvisols in the Pleistocene}

In Central Europe, loess-paleosol sequences (Flašarová et al. 2020, Antoine et al. 2013) contain several different soil types. The most obvious are Luvisols, representing interglacial climatic conditions, similar as to today, and Chernozems, reflecting drier and cooler climate at the beginning of the glacial periods. However, the paleoclimate was oscillating also during the glacial periods, and less well-developed soils such as Regosols, weak Cambisols or tundra Gleys were formed as well (Ložek 1973, Hošek et al. 2015). 
Loess-paleosol sequences are important paleoenvironmental archives because of their long-term continuous paleoclimate record, analogous to marine proxy records or ice core records (e.g. Muhs 2007; Sheldon, Tabor 2009). Paleosols formed at the Earth's surface were in direct contact with the environmental conditions prevailing at the time of their formation and they reflect the prevailing temperature and precipitation. Paleosols can be considered as an equivalent to recent soils with the corresponding morphological signs (Němeček, Smolíková, Kutílek 1990).

\section{Materials and methods}

\subsection{Study site of Hrušov}

The studied catena is situated in the west from the village of Hrušov $\left(50^{\circ} 21^{\prime} \mathrm{N}\right.$, $14^{\circ} 50^{\prime} \mathrm{E}$ ) in Czechia. The catena is located in a flat zone, at the upper part of a plateau covered by a loess. The length of the studied transect is 331.2 meters, its maximal slope inclination reaches $0.6 \%$. The spatial distribution of the examined soils is described in Figure 3.

The parent material is formed by a loess (Česká geologická služba 2013). The annual precipitation reaches between 500 and $600 \mathrm{~mm}$, the mean annual temperature varies between $8^{\circ} \mathrm{C}$ and $9^{\circ} \mathrm{C}$. The evapotranspiration reaches 550 to $600 \mathrm{~mm}$ (Tolasz et al. 2007).

The Macro-physical Climate model (Bryson, McEnaney DeWall 2007) for Prague-Karlov (ca. $50 \mathrm{~km}$ southwest from Hrušov) shows that from the Weichsel Late-glacial to Boreal period, the precipitation is higher than the evaporation, but the difference is low (Fig. 4). Between 7500 and 5500 BP, the values of the potential evapotranspiration might even exceed the rainfall in the growing season. During

Fig. 3 - The location of the studied soils. Source: ČúZK 2019.

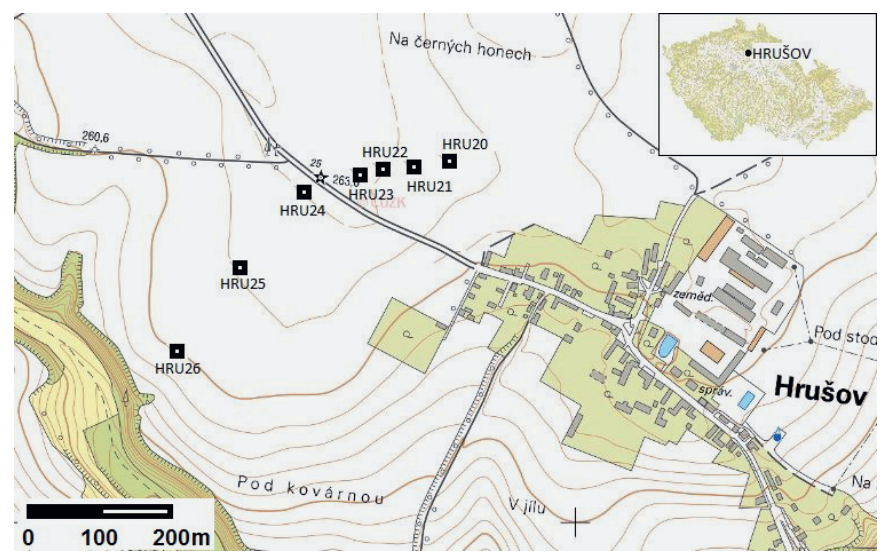




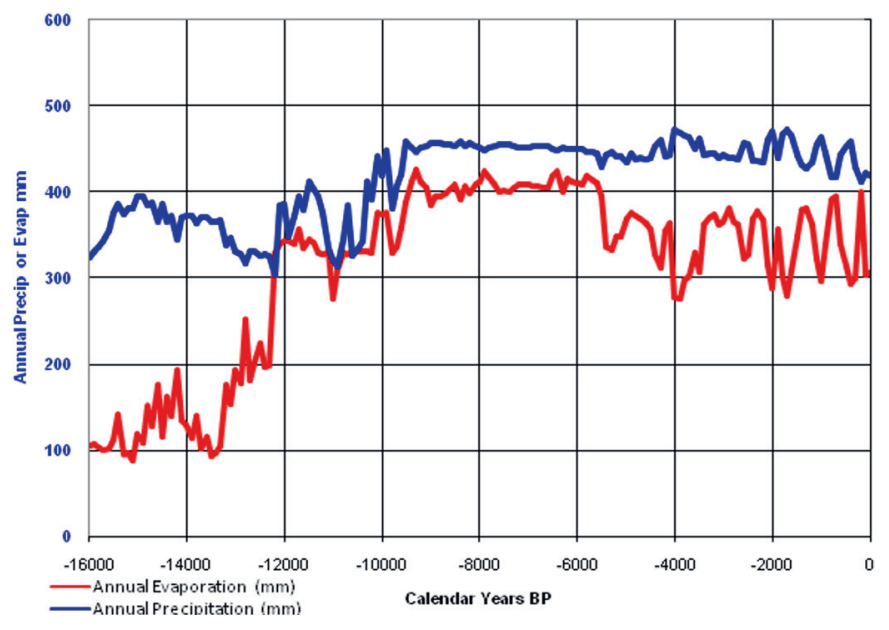

Fig. 4 - The potential mean annual precipitation and evaporation for Prague-Karlov (alt. $261 \mathrm{~m}$ a.s.l.). Source: according to Bryson, McEnaney DeWall (2007). Modelled by Bryson and Cummings.

the Atlantic period, the evaporation decreased while the precipitation stayed relatively constant with more fluctuations. The climate has become relatively more humid and colder with some fluctuations (Dreslerová 2012).

Nowadays, the zone is an arable land with the alternation of various crops: wheat, corn, colza, sugar beet. The region has been settled since the Neolithic period (Pavlů, Zápotocká 2007). The archaeological evidence of Hrušov is quite scarce, there are objects of stroke-ornamented ware ceramics (Neolithic, ca. $5000 \mathrm{BC}$ ), objects from the Únětice culture (ca. 2200-1600 BC). Most of the objects found come from the Lusatian culture and the Hallstatt one (ca. 1000-400 BC) (unpublished archives of the Archaeological Institute, Prague). The village was documented in historical documents for the first time in 1346.

\subsection{Soils in the catena}

Through the paper, we use the WRB 2014 soil classification (FAO 2015). Seven pits labelled HRU20, HRU21, HRU22, HRU23, HRU24, HRU25 and HRU26 (Fig. 5) were dug in order to proceed with a detailed physical and chemical analysis and a micromorphological study of soils in the catena. The exact location of the pits (determined by GPS and TST) is indicated in Table 2 and Figure 5.

According to the soil morphology, there are three types of soils in the catena of Hrušov: Haplic Chernozem, Luvic Chernozem and Luvisol (Fig. 5). The Chernozem marked as HRU21 has a chernic horizon. It is partly ploughed down to the depth of $43 \mathrm{~cm}$ - the $\mathrm{A}$ and $\mathrm{C}$ horizons are mixed in there. The A horizon is compacted by ploughing; it is partially decarbonated. There are loess dolls and numerous lombric galleries in the $\mathrm{C}$ horizon (Fig. 5). The profiles of HRU20, HRU22 and HRU23 
Tab. 2 - The list of the studied pits at the site of Hrušov

\begin{tabular}{|c|c|c|c|}
\hline \multirow[t]{2}{*}{ Profile Code } & \multicolumn{2}{|c|}{ Coordinates } & \multirow{2}{*}{$\begin{array}{l}\text { Soil } \\
\text { type }\end{array}$} \\
\hline & $\begin{array}{l}\text { Latitude N } \\
\text { Longitude } \mathrm{E}\end{array}$ & $\begin{array}{l}\text { Altitude } \\
\mathrm{m} \text { a.s.l. }\end{array}$ & \\
\hline HRU20 & $\begin{array}{l}50^{\circ} 20.822^{\prime} \\
14^{\circ} 50.393^{\prime}\end{array}$ & 263.053 & Luvic Chernozem \\
\hline HRU21 & $\begin{array}{l}50^{\circ} 20.816^{\prime} \\
14^{\circ} 50.367^{\prime}\end{array}$ & 263.074 & Haplic Chernozem \\
\hline HRU22 & $\begin{array}{l}50^{\circ} 20.813^{\prime} \\
14^{\circ} 50.345^{\prime}\end{array}$ & 262.997 & Luvic Chernozem \\
\hline HRU23 & $\begin{array}{l}50^{\circ} 20.811^{\prime} \\
14^{\circ} 50.331^{\prime}\end{array}$ & 263.121 & Luvic Chernozem \\
\hline HRU24 & $\begin{array}{l}50^{\circ} 20.805^{\prime} \\
14^{\circ} 50.293^{\prime}\end{array}$ & 263.017 & Luvisol \\
\hline HRU 25 & $\begin{array}{l}50^{\circ} 20.769^{\prime} \\
14^{\circ} 50.228^{\prime}\end{array}$ & 262.323 & Luvisol \\
\hline HRU26 & $\begin{array}{l}50^{\circ} 20.724^{\prime} \\
14^{\circ} 50.171^{\prime}\end{array}$ & 261.815 & Luvisol \\
\hline
\end{tabular}

are Luvic Chernozems with a similar morphology. The transition between them is clear and irregular. Only the HRU20 profile has a preserved part of a natural A horizon between the Ap and the Bt. The profiles of HRU24, HRU25 and HRU26 are Luvisols which are deeply reworked by ploughing. Therefore, the E horizon and the upper part of the Bt horizon are mixed together and the limit between the ploughing horizon and the Bt horizon is sharp (Fig. 5).

\subsection{Soil micromorphology}

The soil micromorphology studies the undisturbed samples under a petrographic microscope to identify various soil components and to analyse their organisation. At a very fine scale, it allows one to observe the processes and dynamics that are macroscopically hardly perceptible or not perceptible at all (Fedoroff, Bresson, Courty 1987, Stoops 2003, Stoops, Marcelino, Mees 2010).

Following the field observation, the microscale observation highlights the natural evolution of the soils, like various changes in the vegetation cover (Smolíková 1969) or anthropogenic activities, e.g., ancient agricultural practices (Gebhardt 1995; Deák et al. 2017; Macphail, Goldberg 2017). This helps to better understand the local evolution of the landscape (Gebhardt, Fechner, Occhietti 2014). The micromorphological approach is based on the study of 15 thin sections of the profiles HRU21 (Haplic Chernozem), HRU20, HRU23 (Luvic Chernozem) and HRU24 (Luvisol). The thin sections are described following the international soil thin section description methods (Bullock et al. 1985, Stoops, Marcelino, Mees 2010). 

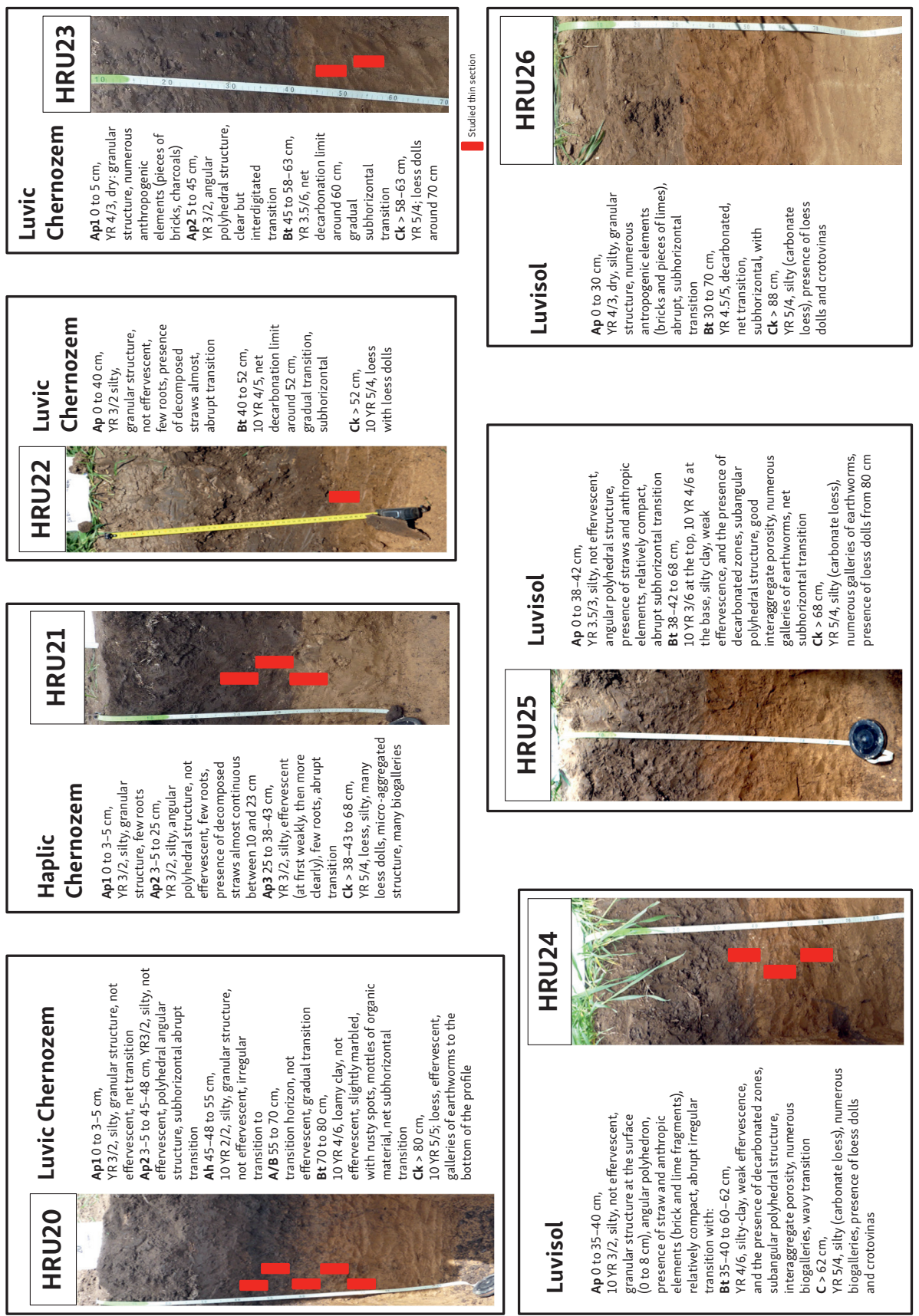

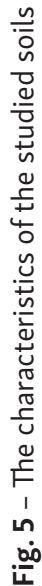




\subsection{Soil analyses}

Samples, of approximately $50 \mathrm{~g}$, were taken at every $5 \mathrm{~cm}$ in depth from each studied soil (except from HRU22). They were dried at $40^{\circ} \mathrm{C}$ and sieved to pass through a $2 \mathrm{~mm}$ mesh. The particle-size distribution was measured with a laser granulometer (type Beckmann-Coulter LS230). Before the measurement of the particle-size distribution was made, the samples had been treated by $\mathrm{H}_{2} \mathrm{O}_{2}$ to destroy the SOM (soil organic matter). The samples had been washed by $\mathrm{KCl}$ also, distilled water and sodium hexametaphosphate to deflocculate the aggregates without destroying the carbonates. The total organic carbon (TOC) was estimated by near-infrared spectroscopy (Cécillon et al. 2009). The content of $\mathrm{CaCO}_{3}$ was quantified by measuring the volume of the $\mathrm{CO}_{2}$ lost in the reaction with the $\mathrm{HCl}$ in a closed atmosphere.

\section{Results}

\subsection{Analytical properties}

The interpretation must take into consideration that soils are farmed intensively. Agricultural techniques include the application of common agricultural amendments and deep ploughing down to $45 \mathrm{~cm}$. We observed that the predominant fraction in all the analysed soils was the silt fraction (Fig. 6). It generally represents between 63 and $68 \%$ of the mineral fraction. The clay fraction represents between 15 and $26 \%$ of the mineral fraction depending on the soil. The clay content is relatively constant, except Luvisol HRU24 where a clay peak appears clearly in the Bt horizon. This trend is much less pronounced in the Luvisol HRU25 and the HRU26. These two profiles are clearly Luvisols according to the morphology in the field. It must be pointed out that the clay content in the loess parent material is important (from 20 to 23\%). The particle size measurements were performed without decarbonation, which may have caused the aggregation of the clays. The fine sand content is about 10 to $14 \%$, the coarse sand is zero or almost zero. Some coarse sands are elements of anthropogenic waste (bricks or lime pieces).

The $\mathrm{pH}$ values reach between 6.7 and 8.4. The differences between the Luvisols and the Chernozems are not significantly marked due to the agricultural calcimagnesic amendments (we observed lime fragments during the field observations and in the thin sections as well) applied to the soils.

All the studied soil profiles contain $\mathrm{CaCO}_{3}$. In the surface horizons, the $\mathrm{CaCO}_{3}$ content varies between 0 and $3 \%$. Its maximum is reached in the $\mathrm{Ck}$ horizon.

The total organic content (TOC) of the studied soils, assessed between 0 and $2 \%$ is relatively stable in the ploughing horizons. The $\mathrm{Bt}$ in the Luvic Chernozem 
TOC (\%)

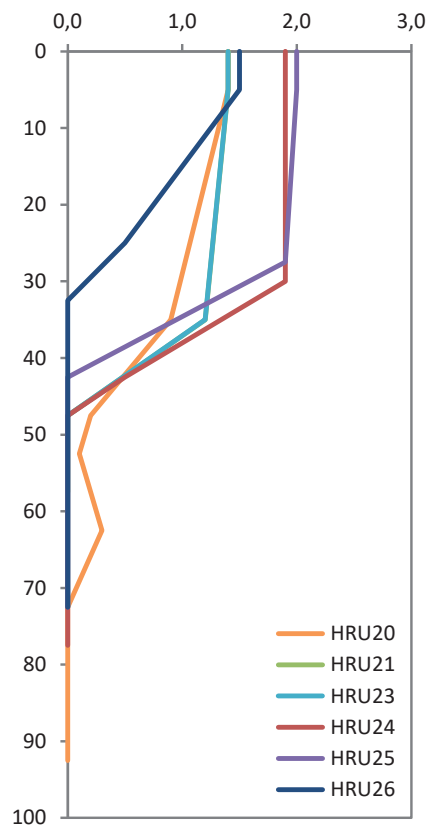

Clay (\%)

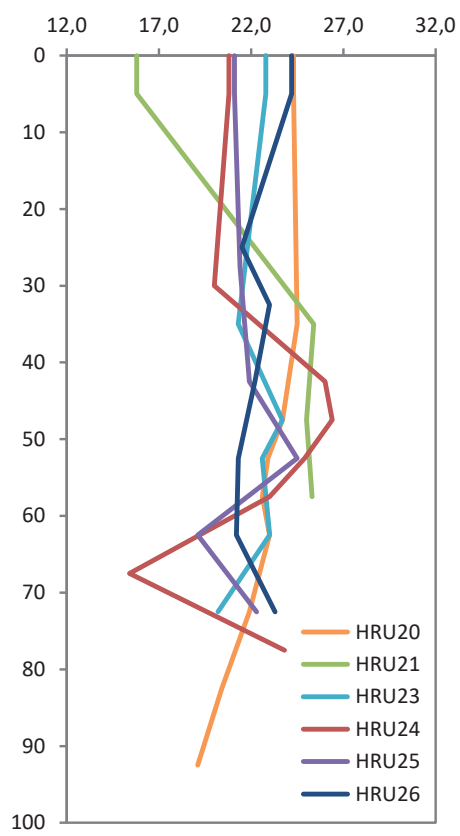

pH

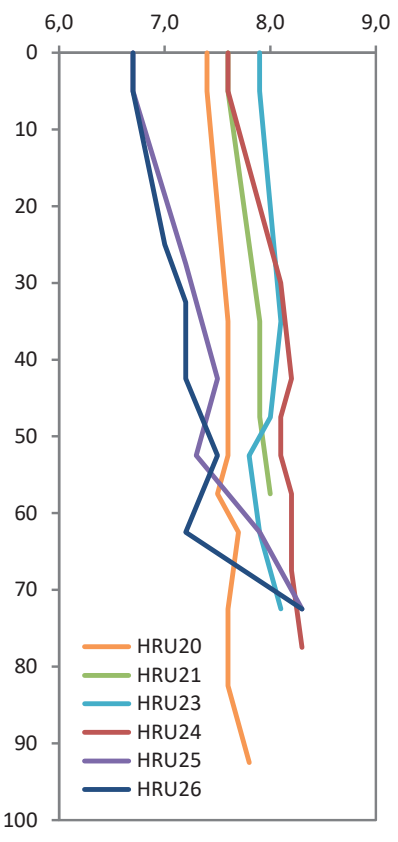

\section{$\mathrm{CaCO}_{3}(\%)$}

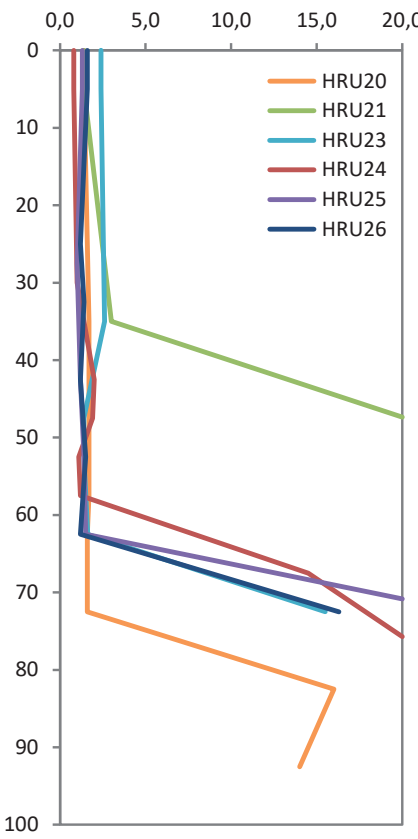

Fig. 6 - The $\mathrm{TOC}, \mathrm{CaCO}_{3}$, clay contents and pH of the studied soils in the Hrušov catena 


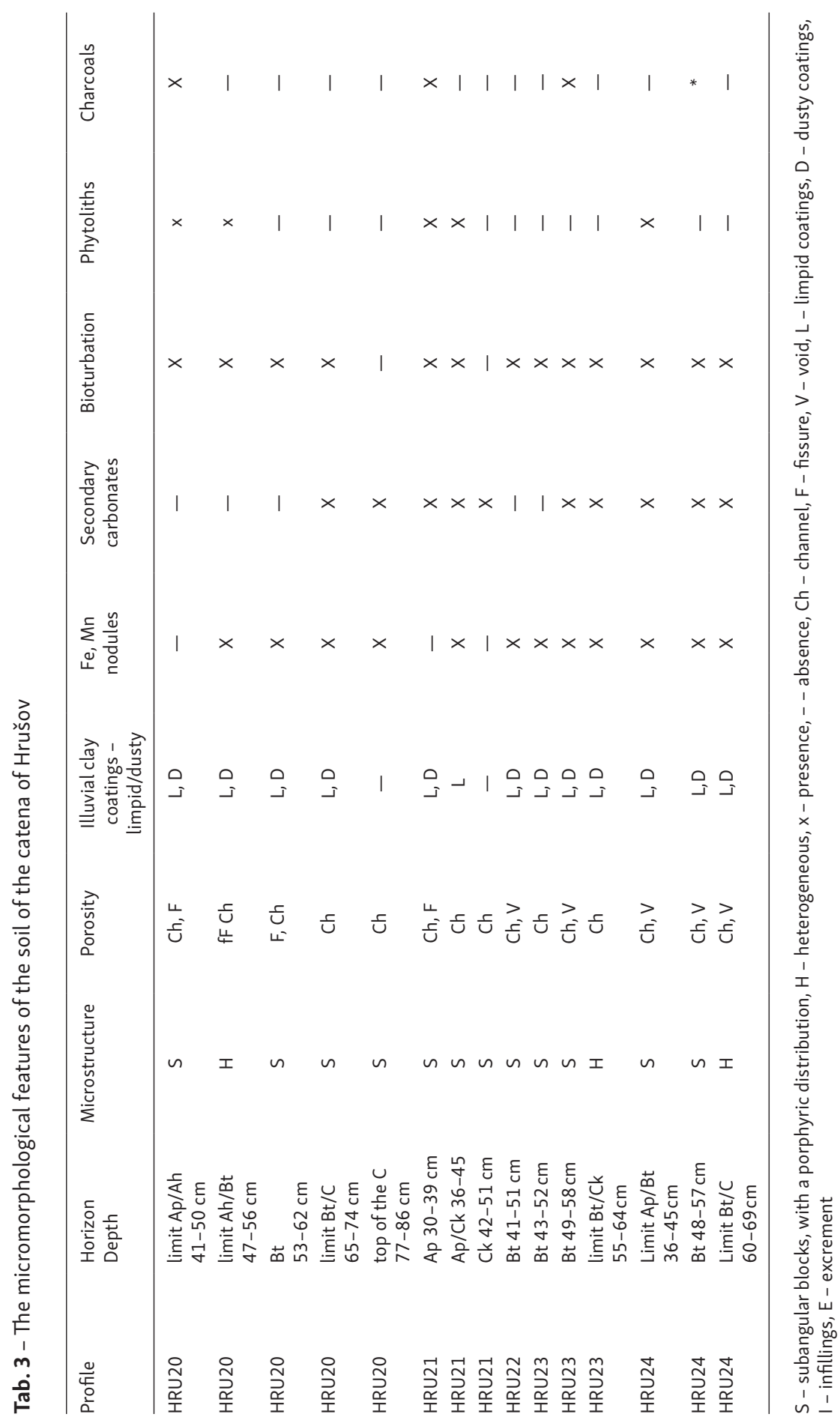


shows a trend of slow a decrease in the TOC with the depth. The contents of the TOC in Luvisols fall sharply under the Ap horizon.

\subsection{Micromorphological observations}

The micromorphological observations have been preferentially undertaken in the horizons beneath the Ap (Table 3).

\subsection{Micromorphological evidence of the pedogenic processes}

\subsubsection{Luvisol HRU24}

At the Ap/Bt limit, we can observe traces of bioturbation and many bio-galleries filled with silt. Dusty silty-clay coatings are clearly visible. They correspond to the splash effect of rain on naked soil surfaces and are common in the actual or in an ancient arable land (Jongerius 1970; Macphail, Courty, Gebhardt 1990; Deák et al. 2017). In the lower part of the Bt horizon, there are also yellow-orange and limpid clay coatings, which are considered to be typical for the leaching environmental conditions (Macphail, Courty, Gebhardt 1990, Gebhardt 1993).

The well-developed luvic Bt horizon, which appears just under the Ap horizon, suggests that deep ploughing homogenised the upper A and $\mathrm{E}$ horizons.

In the Bt horizon, there are sparitic carbonate coatings on clay illuviations (Fig. 7). The carbonate hypo-coatings are formed inside the larger pores by water evaporation or by a sudden decrease in the $\mathrm{CO}_{2}$ in the soil (Zamanian, Pustovoytov, Kuzyakov 2016).This fact indicates that the phases of carbonatation succeeded the phases of leaching as a consequence of a shift in the environmental conditions. This observation is coherent with the analytical data that indicate the presence of small amounts of carbonates in the Bt horizon.

\subsubsection{Haplic Chernozem HRU21}

In the Ap horizon, the silts (loess) are well sorted and homogeneous and form a porphyric ground mass. The fine matrix is very organic and bioturbated. There are fragments of mollusc shells, phytoliths, charcoals, ferruginous concretions and lime fertiliser grain fragments. The observation of the residues of non-decomposed organic matter corresponds to the observations made in the field.

In the Ap horizon and at the limit of the Ap and $\mathrm{Ck}$ horizons, there are clear clay coatings of a limpid yellow or orange colour that are completely reworked by ploughing (not in situ). These coatings are relics of a former existence of a luvic Bt 


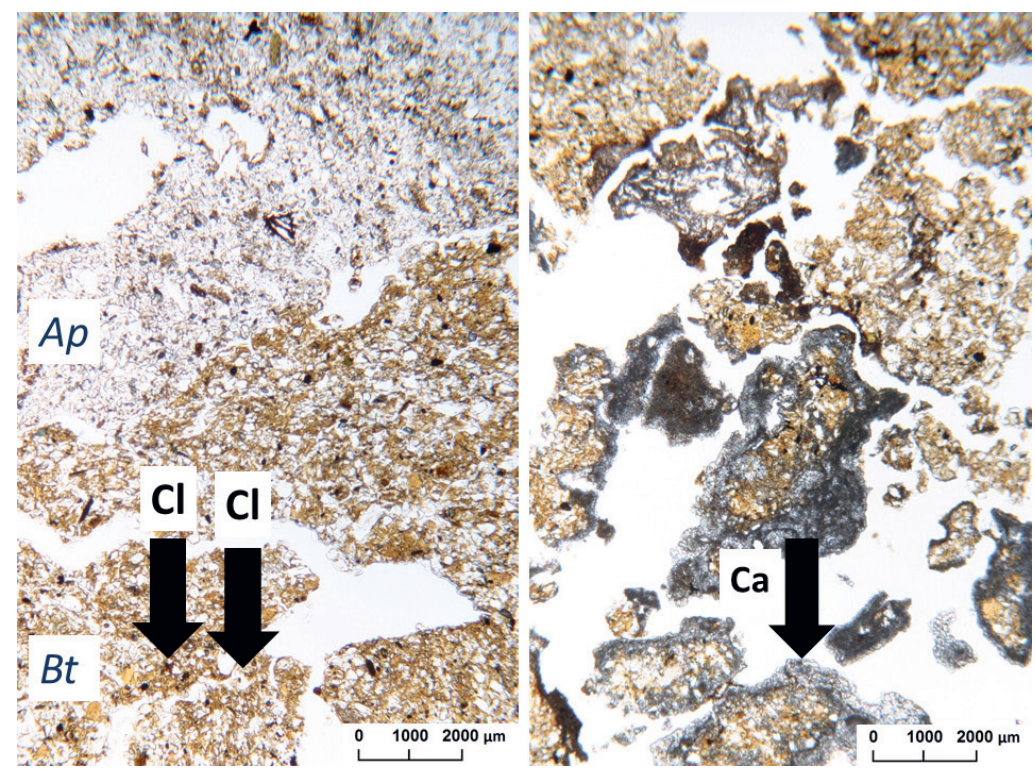

Fig. 7 - Soil HRU24 - Left: the Bt horizon of the relict Luvisol. The calcareous coatings (Ca) over the clay coatings $(\mathrm{Cl})$ are evidence of post-luvic re-carbonation. Right: The micritised mass of the Bt horizon.
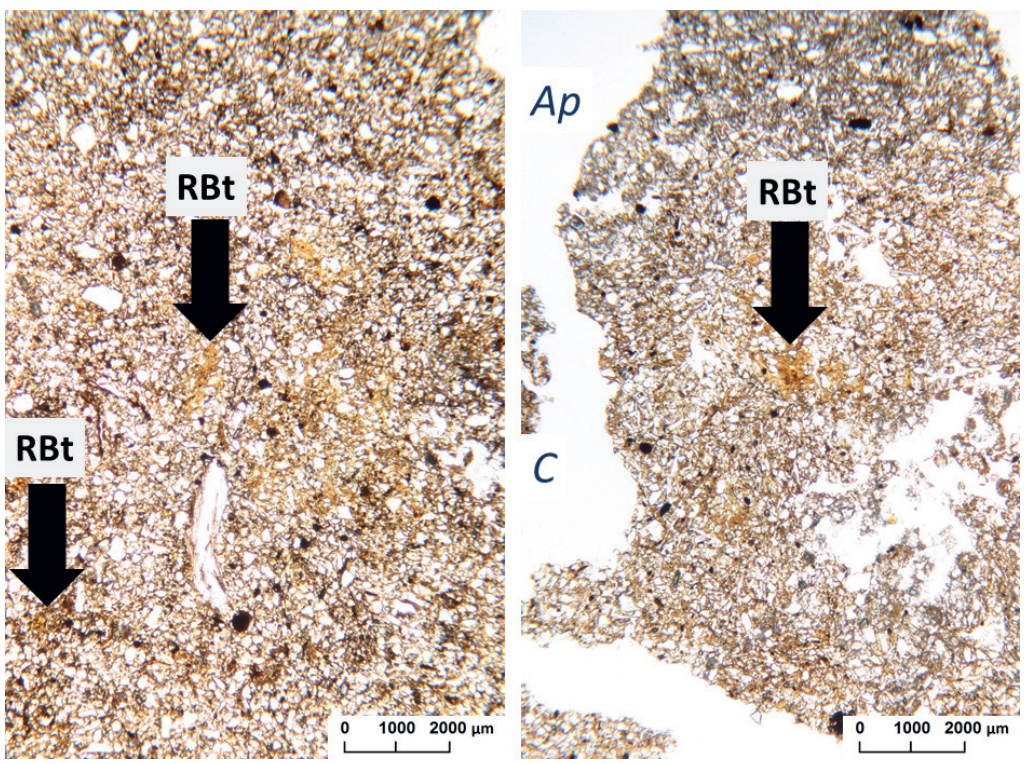

Fig. 8 - Soil HRU21 - Limpid, dislocated yellow-orange clay coatings, which attests to the existence of a reworked ancient Bt horizon (RBt) in the Ap horizon (on the left) and in the Ap horizon at the limit between the ploughing and the $\mathrm{C}$ horizons (on the right). 


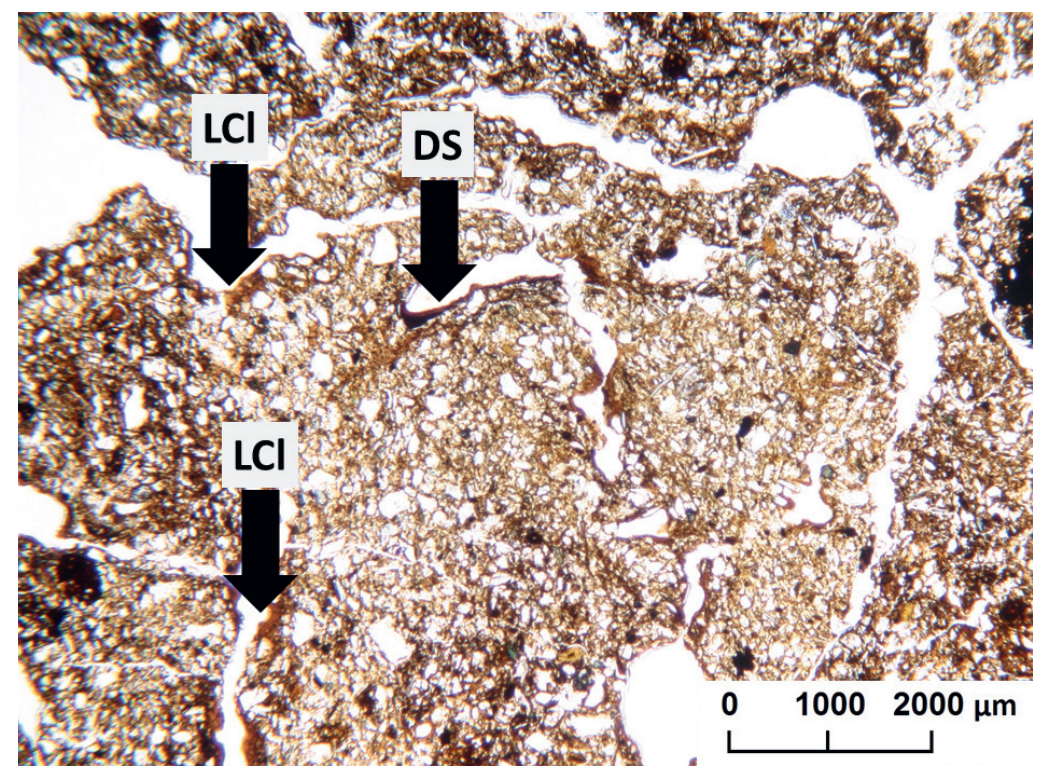

Fig. 9 - The soil HRU20, the Bt horizon of the Luvic Chernozem. The yellow-orange limpid clay coatings ( $\mathrm{LCl}$ ), partly dislocated and thin brown dusty silty coatings (DS) in the Bt horizon.

horizon which disappeared (Fig. 8). In the Ck horizon, the micromass is micritic with a secondary calcareous precipitation in an acicular form. They may be caused by the climatic condition between the last tillage and the sampling. Secondary carbonates are also present in the form of small nodules.

\subsubsection{Luvic Chernozem HRU20}

We focused on the examination of the thickest profile HRU20 that contains - under the ploughing horizon - residues of the Ah horizon which are undisturbed by tillage. The micromass of Ap and Ah is humic, due to the strong bioturbation, it is heterogenous, with fissured porosity. The main observed feature is the simultaneous presence of the dusty coating and limpid yellow coating horizons (Fig. 9).

The main observed pedofeatures are: dusty clay/silt coatings (limit Ap/Ah), phytoliths (limit Ap/Ah and limit Ah/Bt) and a strong bioturbation (Ap, Ah and $\mathrm{Bt})$. The most important observations are the simultaneous presence of the limpid yellow-orange clay coatings in situ - sometimes reworked by bioturbation - and the dusty clay/silty coatings coming from the bare ploughed surface. 

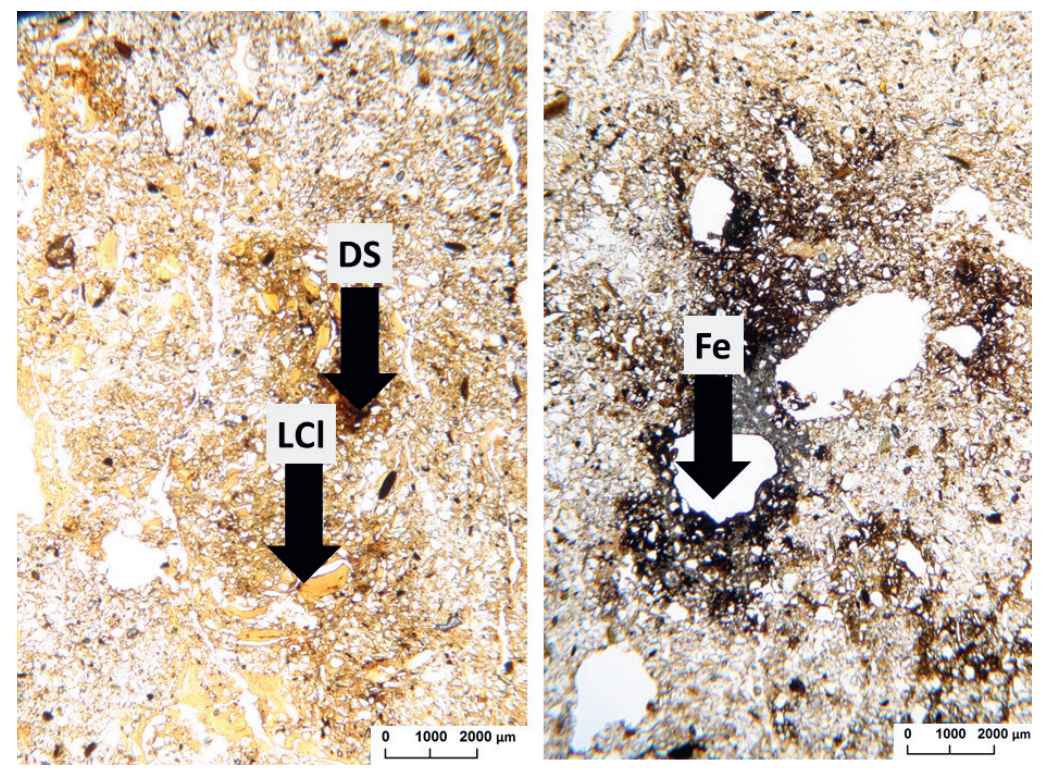

Fig. 10 - Soil HRU23: Yellow-orange limpid clay coatings (LCl), and thin brown dusty silty coatings (DS) in the Bt horizon of the Luvic Chernozem (on the left). Grey micritic stains of root origin and impregnations of $\mathrm{Fe}(\mathrm{Fe})$ on the calcareous concretions in the $\mathrm{Ck}$ horizon (on the right).

\subsubsection{Luvic Chernozems HRU22 and HRU23}

The two soil profiles of the Luvic Chernozems, HRU22 and HRU23, are very similar. Here again, the most important observation, in the Bthorizons, is the simultaneous presence of the limpid yellow-orange clay coatings in situ - sometimes reworked by bioturbation - and the dusty silty coatings coming from the bare ploughed surface.

In both soils, there are ferruginous concretions, which prove the humidity of the site. In the $\mathrm{Ck}$ horizon of HRU23, there are grey micritic hypo-coatings (Fig. 10).

\subsection{Interpretation of the soil evolution}

The simultaneous presence of the yellow-orange limpid clay coatings, the brown dusty silt coatings and the signs of re-carbonation clearly indicate that the observed catena is of a polygenic origin. According to our observation, we hypothesise that the soils at the site of Hrušov passed a three-stage evolution. 


\subsubsection{First phase}

We suppose that before the arrival of the first farmers, the formation of the soil happened in a natural way. The natural late glacial surface, bare loess, used to be not so flat as today (Pavlů, Zápotocká 2007). The first stage of pedogenesis in the Holocene is characterised by the formation of a humic horizon on the loess sediment.

Then, we observe a phase of forestation which is perceptible due to the limpid yellow-orange clay coatings. It corresponds to the clay leaching of the decarbonated upper horizons under the forest vegetation before the agricultural practices were set up. We suppose Luvisol used to be present at the site at that time.

\subsubsection{Second phase}

The second phase is linked to the beginnings of the agriculture. The agriculture was set up by the deforestation and the reintroduction of steppe conditions. The culture of cereals simulates the steppe vegetation of Poaceae by high inputs of soil organic matter by the root system. The setup of the agriculture leads to erosion processes and the levelling of the surface. Part of the observed features is due to the colluviation. The Chernozem at the top of the catena may be considered as a product of the polygenic evolution, erosion and re-carbonation by bioturbation (Fig. 11).

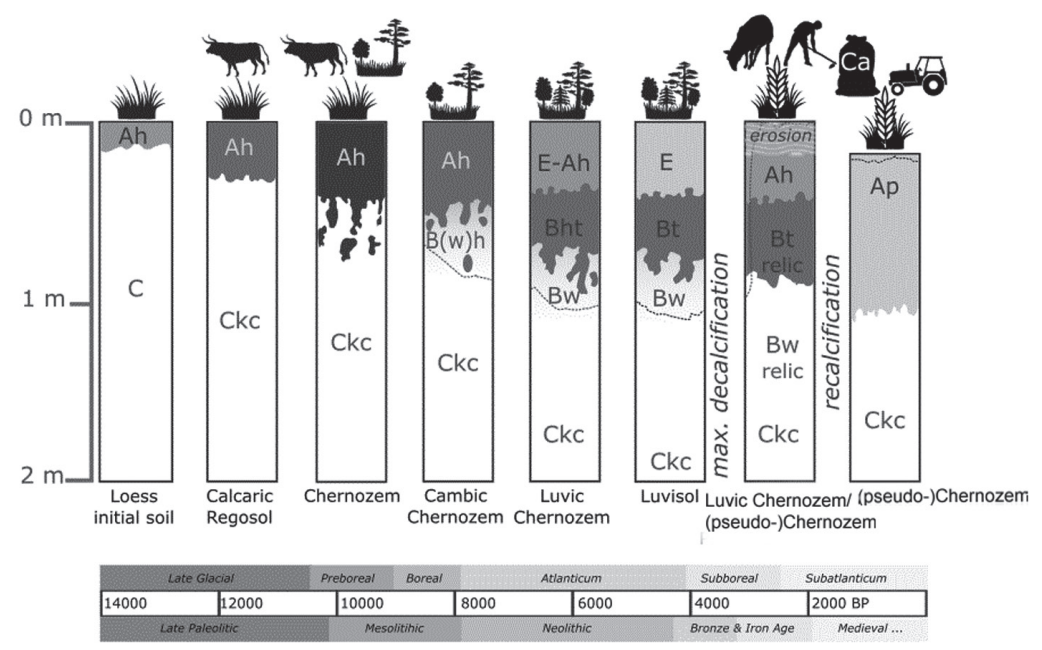

Fig. 11 - The retrograde evolution of the Chernozem at the site of Hrušov 
The second phase observed in the Bt horizon is marked by dusty, brown silty coatings. This second stage could have started as early as the beginning of the soil cultivation. The Luvisol at the lower part of the catena became thicker, the cultivation and organic amendments lead to the destruction of the Ap and E horizons. According to acquired data, we cannot state if the zone was deforested at the same time or in multiple phases.

\subsubsection{Third phase}

Later on, we identified the third stage of the soil formation. It is characterised by the carbonate precipitation on the clay coatings in the Bt horizon. This stage of carbonatation has to be linked to the new input of carbonates. This input can be caused by natural and human factors, it is confirmed by the unusual high $\mathrm{pH}$ of all the studied soils.

Our observations may lead to the conclusion that the differentiation of the soil types, which must be a consequence of an environmental change that originated in a long-term shift in the vegetation. The factor of the vegetation change, which was induced by human activities in the area, dominates the pedogenesis of these soils. The deforestation led to the change in the leaching parameters of the soils and the change in the acidification processes. An inorganic amendment and an organic waste, dung from households have been applied because the land has been used as an arable field. This is supported by findings of sherds and pieces of bricks found in the fields around the village. The third phase ends with the modern agriculture period, which completed the re-carbonation of the soil by deep ploughing and inorganic inputs and terrain levelling.

\section{Discussion}

The observations do not offer unique and clear interpretations. In addition, we must remind one that the knowledge of the past soil cover is very fragmentary. If soils have developed since the end of the last ice age (Duchaufour 1998), they were, at the time of the arrival of the first farmers, about at half-time of their current development. Their physico-chemical characteristics were undoubtedly different from those known today. However, the reasoning held on the evolutionary series are all made on the basis of the observation of the present soils. 


\subsection{Transformation of the soils}

The soil transformation from Chernozem to Luvisol requires the decarbonation of the Chernozem as a consequence of an increase in the precipitation, intensifying a change in the leaching conditions and of the induced shift in the vegetation. Then the transformation from Luvisol to Chernozem would need the re-carbonation and decline of the Bt horizon.

Nowadays, the $\mathrm{pH}$ of the studied soils is too high to be convenient for clay illuviation (Quénard et al. 2011). Calcium forms between the clay and the soil organic matter, a very strong complex which does not enable the dispersion of clays and their migration (Mason et al. 2016).

Our observations of the soils in the examined catena showed that there are relicts of the yellow-orange limpid clay coatings in almost every examined soil profile. We may conclude that those features are relicts from the period when the $\mathrm{pH}$ used to be lower (before re-carbonation). The yellow-orange clay coatings are not typical micromorphological features in the Chernozem (FAO 2015), because clay illuviation follows the profile decarbonation (Duchaufour 1998, Van Vliet-Lanoë 1992). For example, Smolíková (1972) demonstrates a typical spongy structure of Chernozems on the A horizon from a fossil Pleistocene soil.

The micromorphological observation in Hrušov reveals that the yellow-orange limpid clay coatings are trapped under the secondary carbonates. This fact demonstrates that the process of the translocation of clay is older than the recarbonation. The process of the translocation of the clay is also not active anymore. The yellow-orange limpid clay coatings are not in situ - they were dislocated by the bioturbation that followed the stage of illuviation.

At the same time, the bioturbation is a natural way of the re-carbonation and destruction of Bt horizon. The presence of fauna is proved by the observation of krotovinas and of numerous lombric galleries in the studied soils. The recarbonatation is a result of the liming.

Last, but not least, it must be mentioned that these processes can occur under climates convenient for the existence of Chernozems (Němeček et al. 2011, Table 1), in the so-called ancient forest-steppe zone (Ložek, Smolíková 1978).

\subsection{Role of erosion}

We have to consider that the process of re-carbonation may partly be a result of erosion. Even if the surface is quite levelled now, the inclinations could have been steeper in the beginning of the agricultural era (Pavlů, Zápotocká 2007). This theory is supported by the different depths of the soil profiles. The Chernozems situated in the upper part of the catena are as deep as the Luvisols down the slope. 
Soil erosion is an inevitable consequence of deforestation and soil ploughing since the beginnings of agriculture (Dreslerová et al. 2019). According to the map of the long-term loss by erosion in the studied area, it reaches between 1 and 4 t.ha $^{-1}$.year ${ }^{-1}$ (https://mapy.vumop.cz/; 15.4.2019). Studies concerning the erosion in prehistoric and historic times estimate that the soil loss by erosion on loess can reach an average rate of several t.ha ${ }^{-1} \cdot \mathrm{yr}^{-1}$ (Froehlicher et al. 2016, Kołodyńska-Gawrysiak, Poesen, Gawrysiak 2018).

When we consider the erosion rates on a centennial or millennial scale, the soil loss may have reached more decimetres. In the upper part of the catena, the residues of the surface horizons are homogenised by modern mechanisation. Therefore, the Bt horizon cannot be observed anymore. The tillage, the uplift of the carbonates and the colluviation could have caused the re-carbonation down the slope.

At the same time the partial decrease of the soil level in the upper parts of the catena causes that the carbonates (loess) can be found at a shallower depth, which facilitates the upwelling by bioturbation. In a typical Luvisol on loess, the carbonates appear at depths of $100-110 \mathrm{~cm}$, which limits the bioturbation to return the carbonates into the soil profile.

The mentioned processes led to the transformation of the natural properties of the soil, especially the $\mathrm{pH}$ values and grain-size distributions. The soils have become more unified especially in the texture and organic contents.

\subsection{Role of vegetation}

According to the micromorphological findings, we assume there used to be a forest at the site of Hrušov in the past. The conclusion is supported by the climate model (Bryson, McEnaney DeWall, 2007) which shows conditions for the development of a forest. As described above, the Chernozems degrade to Luvisols under stable forest conditions Němeček, Smolíková, Kutílek (1990).

The role of the vegetation, especially in the "Chernozem question" has been largely discussed. According to Ložek (1973), the Chernozems under a steppe were conserved (not degraded to a Luvisol) until the beginnings of the agriculture in small patches (Fig. 12) and the Luvisols formed in the areas that were not transformed to the agricultural land. Others claim that the first farmers were able to find Chernozems under the woodland or at least under the forest-steppe vegetation (Vysloužilová et al. 2014, Beneš, 2004, Dreslerová 2012, Strouhalová et al. 2019).

On the contrary, the appearance of climax forests is not, according to FischerZujkov, Schmidt, Brande (1999), a factor likely to cause the degradation of Chernozems. Indeed, in the Central European Chernozem extents area, the natural forest must look like an oak grove or an oak grove with an always very dense 


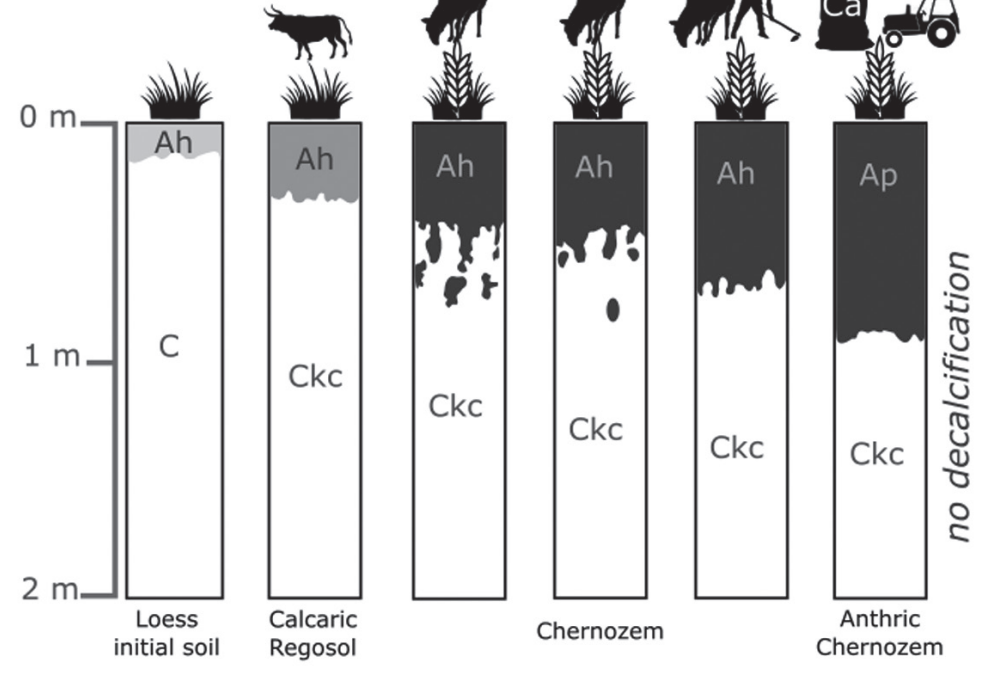

Fig. 12 - The formation of the Chernozems in Central Europe according to Ložek (1973)
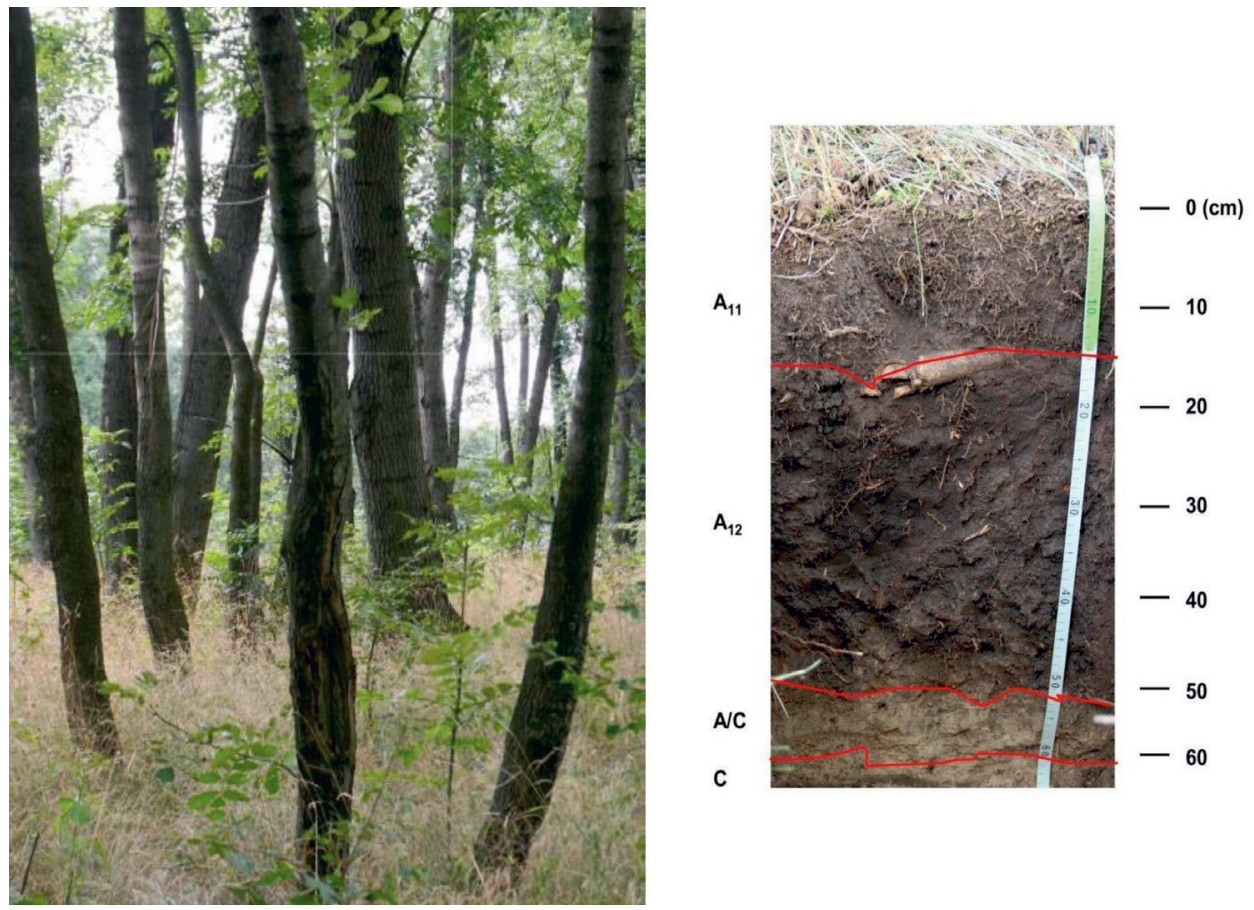

Fig. 13 - A Chernozem under woody vegetation in the Bulhary forest (Czechia). The game preserve has existed at the site since the $13^{\text {th }}$ century. 
herbaceous layer (Fig. 13, Kreuz 2007, Scheffer, Meyer 1963). Under these conditions, the inputs of the organic matter to the soil are not very different between relatively clear forests and steppes, which explains, according to Fischer-Zujkov, Schmidt, Brande (1999), that a Chernozem shows a certain stability under the forest vegetation.

Nonetheless, in the case of our study, it is very hard to imagine a distinct patch of steppe naturally having a different evolution during the thousands of years which would result in the small-scale soil cover differentiation.

\subsection{Retrograde evolution of the soil}

The catena of Hrušov and its characteristics confirm that the site is located in a transition zone. It corresponds to a chronosequence where one type of soil is slowly transforming into the other, and we are able to say that a Luvisol is transformed into a Chernozem.

This conclusion is contradictory to the traditional view of soil formation (e.g., Alexandrovskiy 2000, Lorz, Saile 2011). Our results go beyond the hypothesis that agricultural management prevents the transformation of a Chernozem to a Luvisol (e.g. Duchaufour 1998, Pokorný et al. 2015). It is likely that a set of human influence and agricultural practices induce the forming of the Chernozem. Beneš (2004) proposes the idea that today's presence of Chernozems in the Linear Pottery culture settlements is not a cause, but a consequence of the ancient agricultural exploitation. He claims that a secondary grassland may boost the development of the Chernozem. Our results confirm that the soil evolution in the studied catena occurred in this way.

Even if it is not well known, the suggested affirmation of this soil evolution scheme is not new. The micromorphological analyses carried out in the 1970s by Smolíková presented an identical conclusion (Smolíková 1962, 1969, 1971, 1972; Ložek, Smolíková 1973; Němeček, Smolíková, Kutílek 1990). These authors called these soils pseudochernozems and the processes leading to their formation retrogressive soil evolution. The following agricultural processes are involved in the soil transformation: calcareous-magnesium amendments block the leaching; cereal roots simulate the steppe conditions; the deep ploughing homogenises the soil and the distribution of the organic material into a large thickness.

The soil development recorded a principal turning point in places where woodland alternated with the steppe. The polygenic Chernozem (or pseudochernozem) started to exist when the vegetation on the Luvisols transformed into cultural steppes (Smolíková 1969). By the method of soil micromorphology, we are not able to bring any exact conclusion concerning the time of the vegetation change. We know that agriculture has been present at the site for a very long 
time - for thousands of years. According to Alexandrovskyi (2007), the formation of Chernozems can be achieved within 3000 years. The studied area may have been cleared at different moments of time in history.

In the European loess belt, similar studies concerning the potential of humans to influence the soil properties in an important way have been observed. As a bright example of the retrograde soil evolution, we mention the Luvisols in Belgium where they are considered as man-made Anthrosols (Langohr 2001). In the oceanic conditions, the climax vegetation on the loess soil is a dense forest. In an undisturbed site of the Forêt de Soignes forest, the soil can be characterised as a Retisol (very degraded loess soils), whereas the agricultural land in the region can be characterised as a Luvisol, which means the precursor of a Retisol in the soil evolution series (Langohr 2001). 800 kilometres to the West from the site of Hrušov, we find the same phase shift in the loess soil evolution series as in Hrušov caused by human activity. The genesis of the Luvisols is influenced by the organic and inorganic amendments, pasture in the forest, tillage, erosion and bioturbation (Langohr 2001).

The Phaeozems in Lower Rhine basin and Hallweg loess belt are another example of human induced changes (Gerlach et al. 2006; Kasielke, Poch, Wiedner 2019). In both cases the dark soils were initially described as degraded Chernozems. After deeper analysis they were labelled as Luvic Phaeozems enriched by high amount of black carbon coming from the slash and burn techniques. Here, as well as in the previous cases, the man influenced the pedogenenis by setting up of agricultural practices. In Czechia, there has been so far only one study focused on the black carbon content in Chernozems (Danková, 2012), which did not confirm the fire history of Chernozems. In the Hrušov catena, we recorded presence of some charcoals, but the analysis of black carbon content was not performed.

\section{Conclusion}

The detailed study of the Hrušov catena shows that the given environmental local conditions of the pedogenesis are identical. We can exclude that the role of climate, exposition, relief and parent material play a significant role in the differentiation of the soil cover.

Man influences the natural soils by that measure so that it is hardly able to distinguish between the natural and the anthropogenic soils. The analysed catena is, therefore, an example of a transforming soil system, in which the initial Luvisols are transformed into Chernozems at the top part of the catena. On the other hand, at the lower part of the catena, we observe the conservation of a Luvisol, however considerably reworked by man. As a result of complex processes, we observe a differentiation in the soil cover on a small scale. 
As consequence, Chernozems cannot necessarily be considered as an indicator for the paleoenvironment of a natural steppe. Some Chernozems may have been formed naturally under conditions of a dry continental climate, but there are some Chernozems which are a consequence of the past and present agricultural practices. A Luvic Chernozem is not an obligatory product of the degradation of a Chernozem under humid conditions. Apparently, it can be a product of human influence on the soil forming processes.

Our results are impossible to extrapolate to the whole Chernozem region. It is highly possible that the scenarios of soil formation may be various within large Chernozem regions in Central Europe.

\section{References}

ALEXANDROVSKIY, A.L. (2000): Holocene development of soils in response to environmental changes: the Novosvobodnaya archaeological site, North Caucasus. CATENA, 41, 1-3, 237-248.

ALEXANDROVSKIY, A.L. (2007): Rates of soil-forming processes in three main models of pedogenesis. Revista Mexicana de Ciencias Geológicas, 24, 2, 283-292.

ALTERMANN, M., RINKLEBE, J., MERBACH, I., KÖRSCHENS, M., LANGER, U., HOFMANN, B. (2005): Chernozem-Soil of the Year 2005. J. Plant Nutr. Sci.2005, 168, 725-740.

ANTOINE, P., ROUSSEAU, D.-D., DEGEAI, J.-P., MOINE, O., LAGROIX, F., KREUTZER, S., FUCHS, M., HATTÉ, C., GAUTHIER, C., SVOBODA, J., LISÁ, L. (2013): High-resolution record of the environmental response to climatic variations during the Last Interglacial-Glacial cycle in Central Europe: the loess-palaeosol sequence of Dolní Věstonice (Czech Republic). Quaternary Science Reviews, 67, 17-38.

BAILLY, F. (1972): Zur Problem der Schwartzerde-Bildung in Norddeutschland. Mitteilungen der deutschen bodenkundlichen Gesellschaft, 15, 3-10.

BAIZE, D., GIRARD, M.-C. (2008): Référentiel pédologique. AFES, Vesrailles.

BENEŠ, J. (2004): Palaeoecology of the LBK: earliest agriculturalist and landscape of Bohemia, Czech Republic. In: LBK Dialogues. Studies in the formation of the Linear Pottery Culture. BAR International Series, Oxford, 143-150.

BRYSON, R.A., MCENANEY DEWALL, K. (2007): A paleoclimatology workbook: high resolution, site-specific, macrophysical climate modeling. The Mammoth Site of Hot Springs, Hot Springs.

BULLOCK, P., FEDOROFF, N., STOOPS, G., TURSINA, T., BABEL, U. (1985): Handbook for soil thin section description. Waine Research Publications, Wolverhampton.

CÉCILLON, L., BARTHÈS, B.G., GOMEZ, C., ERTLEN, D., GENOT, V., HEDDE, M., STEVENS, A., BRUN, J.J. (2009): Assessment and monitoring of soil quality using near-infrared reflectance spectroscopy (NIRS). European Journal of Soil Science, 60, 5, 770-784.

Česká geologická služba (2013): Geologická mapa. Česká geologická služba, Praha.

ČÚZK (2019): Geoportál ČÚZK, https://geoportal.cuzk.cz/ (01.01.2019).

CHYTRÝ, M., KUČERA, T., KOČÍ, M. (2001): Katalog biotopů České republiky. AOPK ČR, Praha.

DANKOVÁ, L. (2012): Antrakologie a NMR spektroskopie v paleoekologickém výzkumu černozemí. Př́rodovědecká fakulta UK, Praha. 
DEÁK, J., GEBHARDT, A., LEWIS, H., USAI, M.R., LEE, H. (2017): Soils Disturbed by Vegetation Clearance and Tillage. In: Nicosia, C., Stoops, G. (eds.): Archaeological Soil and Sediment Micromorphology. John Wiley \& Sons, Ltd, Chichester, UK, 231-264.

DOKUCHAEV, V.V. (1883): Russkij Cernozem. Dissertation. Sankt Petersburg.

DRESLEROVÁ, D. (2012): Human Response to Potential Robust Climate Change around 5500 cal BP in the Territory of Bohemia (the Czech Republic). Interdisciplinaria Archaeologica Natural Sciences in Archaeology, III, 1, 43-55.

DRESLEROVÁ, D., KOZÁKOVÁ, R., CHUMAN, T., STROUHALOVÁ, B., ABRAHAM, V., PONIŠTIAK, Š., ŠEFRNA, L. (2019): Settlement activity in later prehistory: invisible in the archaeological record but documented by pollen and sedimentary evidence. Archaeological and Anthropological Sciences, 11, 5, 1683-1700.

DUCHAUFOUR, P. (1998): Handbook of Pedology. A.A. Balkema, Rotterdam, Brookfield.

ECKMEIER, E., GERLACH, R., GEHRT, E., SCHMIDT, M.W.I. (2007): Pedogenesis of Chernozems in Central Europe - A review. Geoderma, 139, 3-4, 288-299.

ESDC (2013): European Soil Data Centre, http://eusoils.jrc.ec.europa.eu/data.html (25.04.2013).

FAO, ISRIC, ISSS (2006): World reference base for soil resources 2006. A framework for international classification, correlation and communication. Food and agriculture organization of the United nations, Rome.

FEDOROFF, N., BRESSON, L.M., COURTY, M.A. (1987): Micromorphologie des Sols - Soil Micromorphology. Association française pour l'étude du sol, Paris.

FISCHER-ZUJKOV, U., SCHMIDT, R., BRANDE, A. (1999): Die Schwarzerden Nordostdeutschland und ihre Stellung in der holozänen Landschaftsentwicklung. J. Plant Nutr. Soil Sci, 162, 1999, 443-449.

FLAŠAROVÁ, K., STROUHALOVÁ, B., ŠEFRNA, L., VERRECCHIA, E., LAUER, T., JUŘIČKOVÁ, L., KOLǍ̌ÍK, P., LOŽEK, V. (2020): Multiproxy evidence of middle and Late Pleistocene environmental changes in the loess-paleosol sequence of Bůhzdař (Czech Republic). Quaternary International International, 552, 4-14, https://doi.org/10.1016/j.quaint.2019.10.004.

FAO (2015): World reference base for soil resources 2014, update 2015 international soil classification system for naming soils and creating legends for soil maps. FAO, Rome.

FROEHLICHER, L., SCHWARTZ, D., ERTLEN, D., TRAUTMANN, M. (2016): Hedges, colluvium and lynchets along a reference toposequence (Habsheim, Alsace, France): history of erosion in a loess area. Quaternaire, 27, 2, 173-185.

GEBHARDT, A. (1993): Evolution du paléopaysage agricole dans le nord-ouest de la France. Apport de la micromorphologie. The Holocene, 3, 3, 333-341.

GEBHARDT, A. (1995): Soil micromorphological data from experimental and traditional agriculture. Archaeological sediments and soils: analysis, interpretation and management, Archetype press, London, https://hal.archives-ouvertes.fr/hal-02275501/document, 5-40.

GEBHARDT, A., FECHNER, K., OCCHIETTI, S. (2014): Grandes phases de pédogenèse, d'érosion et d'anthropisation des sols au cours de la seconde moitié de l'Holocène en Lorraine (France). ArcheoSciences, 1, 38, 7-29.

GERLACH, R., BAUMEWERD-SCHMIDT, H., VAN DEN BORG, K., ECKMEIER, E., SCHMIDT, M.W.I. (2006): Prehistoric alteration of soil in the Lower Rhine Basin, Northwest Germany archaeological, 14C and geochemical evidence. Geoderma, 136, 1-2, 38-50.

HAASE, D., FINK, J., HAASE, G., RUSKE, R., PÉCSI, M., RICHTER, H., ALTERMANN, M., JÄGER, K.-D. (2007): Loess in Europe - its spatial distribution based on a European Loess Map, scale 1:2,500,000. Quaternary Science Reviews, 16, 9-10, 1301-1312. 
HAUPTMAN, I., KUKAL, Z., POŠMOURNÝ, K., NĚMEC, J. (2009): Půda v České republice. Ministerstvo životního prostředí a Ministerstvo zemědělství, Praha.

HEJCMAN, M., HEJCMANOVÁ, P., PAVLŮ, V., BENEŠ, J. (2013): Origin and history of grasslands in Central Europe - a review. Grass and Forage Science, 68, 3, 345-363.

HOŠEK, J., HAMBACH, U., LISÁ, L., GRYGAR, T.M., HORÁČEK, I., MESZNER, S., KNÉSL, I. (2015): An integrated rock-magnetic and geochemical approach to loess/paleosol sequences from Bohemia and Moravia (Czech Republic): Implications for the Upper Pleistocene paleoenvironment in central Europe. Palaeogeography, Palaeoclimatology, Palaeoecology, 418, 344-358.

JONGERIUS, A. (1970): Some morphological aspects of regrouping phenomena in Dutch soils. Geoderma, 4, 3, 311-331.

KABAŁA, C., PRZYBYє, A., KRUPSKI, M., ŁABAZ, B., WAROSZEWSKI, J. (2019): Origin, age and transformation of Chernozems in northern Central Europe - New data from Neolithic earthen barrows in SW Poland. CATENA, 180, 83-102.

KASIELKE, T., POCH, R.M., WIEDNER, K. (2019): Chernozem relics in the Hellweg Loess Belt (Westphalia, NW Germany) - Natural or man-made? Quaternary International, 502, 296-308.

KOŁODYŃSKA-GAWRYSIAK, R., POESEN, J., GAWRYSIAK, L. (2018): Assessment of longterm Holocene soil erosion rates in Polish loess areas using sedimentary archives from closed depressions: Assessment of soil erosion rates in loess areas using CDs. Earth Surface Processes and Landforms, 43, 5, 978-1000.

KREUZ, A. (2007): Closed forest or open woodland as natural vegetation in the surroundings of Linearbandkeramik settlements? Vegetation History and Archaeobotany, 17, 1, 51-64.

LANGOHR, R. (2001): L'anthopisation du paysage pédologique agricole de la Belgique depuis le Néolithique ancien - Apport de l'archéopédologie. Étude et Gestion des Sols, 8, 2, 103-118.

LESER, H., MAQSUD, N. (1975): Spätglaziale bis frühhlozäne Steppenbodenbildung und Klimaentwicklung im südlichen Rheinhessischen Tafel- und Hügelland. Eiszeitalter und Gegenwart, 26, 118-130.

LORZ, C., SAILE, T. (2011): Anthropogenic pedogenesis of Chernozems in Germany? - A critical review. Black Soils and Black Sediments - Archives of Landscape Evolution, 243, 2, 273-279.

LOŽEK, V. (1973): Př́roda ve čtvrtohorách. Academia, Praha.

LOŽEK, V., SMOLÍKOVÁ, L. (1973): Der Bodenkomplex von Velký Hubenov als Beispiel einer retrograden Bodenentwicklung im Laufe der Nacheiszeit. Časopis pro mineralogii a geologii, 18, 4, 365-383.

LOŽEK, V., SMOLÍKOVÁ, L. (1978): Die nacheiszeitlichen Bodenabfolgen von Poplze und Štětí als Beleg der Boden- und Landschaftentwicklung im Böhmischen Tschernosemgebiet. In: Beiträge zur Quatär- und Landscahftsforschung Festschrift zum 60. Geburtstag von Julius Fink. Verlag F. Hirt, Wien, 531-549.

MACPHAIL, R.I., COURTY, M.A., GEBHARDT, A. (1990): Soil micromorphological evidence of early agriculture in North West Europe. World Archaeology, 22, 1, 53-69.

MACPHAIL, R.I., GOLDBERG, P. (2017): Applied Soils and Micromorphology in Archaeology. Cambridge University Press.

MASON, J.A., JACOBS, P.M., GRULEY, K.E., REYERSON, P., HANSON, P.R. (2016): Parent material influence on soil response to vegetation change, Southeastern Minnesota, U.S.A. Geoderma, 275, 1-17.

MUHS, D. (2007): Loess deposits, origins and properties. Elsevier, 1405-1418. 
NĚMEČEK, J., MACKŮ, J., VOKOUN, J., VAVŘíČEK, D., NOVÁK, P. (2001): Taxonomický klasifikační systém půd ČR. ČZU Praha a VÚMOP Praha, Praha.

NĚMĚČEK, J., MÜHLHANSELOVÁ, M., MACKŮ, J., VOKOUN, J., VAVŘÍČEK, D., NOVÁK, P. (2011): Taxonomický klasifikační systém půd. 2. upravené vydání. Praha.

NĚMEČEK, J., SMOLÍKOVÁ, L., KUTÍLEK, M. (1990): Pedologie a paleopedologie. Academia, Praha.

NEUHÄUSELOVÁ, Z. (1998): Mapa potencionální přirozené vegetace České republiky. Academia, Praha.

PAVLŮ, I., ZÁPOTOCKÁ, M. (2007): Archeologie pravěkých Čech. Sv. 3 Neolit. Archeologický ústav AV ČR, Praha.

POKORNÝ, P., CHYTRÝ, M., JUŘIČKOVÁ, L., SÁDLO, J., NOVÁK, J., LOŽEK, V. (2015): MidHolocene bottleneck for central European dry grasslands: Did steppe survive the forest optimum in northern Bohemia, Czech Republic? The Holocene, 25, 4, 716-726.

VÚMOP (2019): Půda v mapách, https://mapy.vumop.cz/ (15.4.2019).

QUÉNARD, L., SAMOUËLIAN, A., LAROCHE, B., CORNU, S. (2011): Lessivage as a major process of soil formation: A revisitation of existing data. Geoderma, 16, 135-147.

ROHDENBURG, H., MEYER, B. (1968): Zur Datierung und Bodengeschichte mitteleuropäischer Oberflächenböden (Schwarzerde, Parabraunerde, Kalksteinbraunlehm): Spätglazial oder Holozän? Göttinger Bodenkundliche Berichte, 6, 127-212.

SCHEFFER, F., MEYER, B. (1963): Berührungspunkte der archäologischen und bodenkundlichen Forschung. Neue Ausgrabungen und Forschungen in Niedersachsen, 1, 1-18.

SHELDON, N.D., TABOR, N.J. (2009): Quantitative paleoenvironmental and paleoclimatic reconstruction using paleosols. Earth-Science Reviews, 95, 1-2, 1-52.

SMOLÍKOVÁ, L. (1962): Půdy typu lessivé (parahnědozemě) v okolí Letovic. Časopis pro mineralogii a geologii, VII, 316-321.

SMOLÍKOVÁ, L. (1969): Polygenetické půdy rázu pseudočernozemí v Boskovické brázdě. Časopis pro mineralogii a geologii, 14, 2, 171-178.

SMOLÍKOVÁ, L. (1971): Gesetzmässigkeiten der Bodenentwicklung im Quartär. Eiszeitalter und Gegenwart, 22, 156-177.

SMOLÍKOVÁ, L. (1972): The significance of soil micromorphology for the solution of soil evaluation in the geology of the Quaternary. Third international working-meeting on soil micromorphology Wroclaw, 1969. Zeszyty problemowe postepow nauk rolniczych, 123, 543-557.

STOOPS, G. (2003): Guidelines for Analysis and Description of Soil and Regolith Thin sections. Soil Science Society of America.

STOOPS, G., MARCELINO, V., MEES, F. (2010): Interpretation of Micromorphological Features of Soils and Regoliths. Elsevier.

STROUHALOVÁ, B., ERTLEN, D., ŠEFRNA, L., NOVÁK, T. J., VIRÁGH, K., SCHWARTZ, D. (2019): Assessing the vegetation history of european chernozems through qualitative near infrared spectroscopy. Quaternaire, 30, 3, 227-241.

TOLASZ, R. et al. (2007): Atlas podnebí Česka. Czech Hydrometeorological Institute, Palacký University, Praha, Olomouc.

VAN VLIET-LANOE, B., FAGNART, J.P., LANGOR, R., MUNAUT, A. (1992): Importance de la succession des phases écologiques anciennes et actuelles dans la différenciation des sols lessivés de la couverture loessique d'Europe occidentale: argumentation stratigraphique et archéologique, Science du sol, 30, 2, 75-93. 
VON SUCHODOLETZ, H., TINAPP, C., LAUER, T., GLASER, B., STÄUBLE, H., KÜHN, P., ZIELHOFER, C. (2019): Distribution of Chernozems and Phaeozems in Central Germany during the Neolithic period. Quaternary International, 511, 166-184.

VYSLOUŽILOVÁ, B., DANKOVÁ, L., ERTLEN, D., NOVÁK, J., SCHWARTZ, D., ŠEFRNA, L., DELHON, C., BERGER, J.-F. (2014): Vegetation history of chernozems in the Czech Republic. Vegetation History and Archaeobotany, 23, 97-108.

ZAMANIAN, K., PUSTOVOYTOV, K., KUZYAKOV, Y. (2016): Pedogenic carbonates: Forms and formation processes. Earth-Science Reviews, 157, 1-17.

\section{ORCID}

BARBORA STROUHALOVÁ

https://orcid.org/0000-0002-1430-4967

DAMIEN ERTLEN

https://orcid.org/0000-0002-0324-2342

LUDĚK ŠEFRNA

https://orcid.org/0000-0003-1032-9953

KRISTÝNA FLAŠAROVÁ

https://orcid.org/0000-0002-9176-8829

PETR KOLAŘÍK

https://orcid.org/0000-0003-4440-902X 